\title{
The Impact of Cash Flow Statement of Listed Firms on the Decision of Investors
}

\author{
Duc Dung Nguyen \\ National Economics University, Vietnam \\ Manh Dung Tran \\ National Economics University, Vietnam
}

\begin{abstract}
This resarch is conducted for investigating the impact of cash flow statements on investors' decisions in an inefficient information market like Vietnam. Data were collected from the opinion of 150 investors in the stock market in which 75 investors received information on cash flow statement and 75 investors did not receive information of cash flow statement. We employ descriptive statistics and T-tests to examine the impact of cash flow statements on investors' decisions as well as investor confidence in the lack of information of cash flow statement. The results show that cash flow statement had no effect on investors' decisions but the lack of information on the cash flow statement reduced the confidence in making decisions. Based on the findings, some recommendations are given to investors who need to pay more attention to the cash flow statement in making decisions, and for firms that need to pay more attention to the supply information on cash flow statement.
\end{abstract}

Keywords: Cash flow statement, Decision of the Investor, Inefficient market

DOI: $10.7176 /$ RJFA/10-8-10

Publication date: April $30^{\text {th }} 2019$

\section{Introduction}

For the countries with grown economy, stock market has a very important role especially in the countries need a lot of capital sources to develop like Vietnam. Stock market of Vietnam has been established, come into operation and had a non-stop development stages, however, the investor's wish has sufficient and accurate information from the system of financial statement of firms posted on the stock exchange of Vietnam. If like other countries in the world, regulations on cash flow statement issued in 1992. In Vietnam, prior to the year of 2003, the cash flow statement must not be the compulsory financial statement, so the cash flow statement is not familiar to the investors from knowledge, importance, method of establishing and method of approaching such as the statement of financial position and comprehensive statement.

Together with the process of accounting system gradual completion in conformity with general accounting practice in the world, users of information are much interested in financial statements especially including statement of cash flows (Carlin et al., 2015), making the cash flow statement today is not only simple to set up "to have". In the background of international integration has been occured powerfully, for firms posted on the floor developed with the role and strength in national economy that is necessary to pay more attention in the system of financial statement while there is a statement of cash flows.

However, some opinions showed that investors have not appreciated on the role of cash flow statement especially in a market which has information inefficiently as in Vietnam. Therefore, researching the cash flow statement for the decision of investor has its meaning in argument and practice. This study investigates the impact of the cash flow statement on the decisions on the side of investor trading in stock exchange.

\section{Literature review}

Cash flow statement is researched quite a lot in the world related to the role of providing information on the cash flow statement and influence on the decision of information user.

Role of providing information in the cash flow statement with other statements especially as the comprehensive income statement in which many scientists in the world have paid attention. Allen (2000), Wampler et al. (2009) have appreciated the business efficiency of firm, report of business results will provide the result more accurately than cash flow statement in the explicit information environment. By means of faults on the stock market appeared a lot of problems with the comprehensive statement. Accounting operations have been performed to adjust this statement, this statement has provided the information not quite accurately. Clinch et al. (2000) have provided the opinions very remarkably that is cash flow from operating activities going down will be one of symbols from firm's profit going down immediately in those years. Jackman (2011) continues with that opinion and provide an analysis of firms in the period of 18 years from 1988 - 2005 to recognize the difficulties in finance of firms that is possible to predict the information provided on the cash flow statement. He also recognized the relationship between the information on the cash flow statement in predicting the financial situation of American enterprises. 
Cash flow statement has an important role in providing information. However, Sloan (1996) showed that users of financial statement information often have little reaction to changing information on cash flow statement of firm in a market that information is inefficient. An efficient market as stock price changes according to the information provided in public of firm. In contrast, as the market is inefficient, information provided by the firm posted up will not have an influence on the decision of information user. This is also opinion of Barth et al. (2001) on the efficiently information market. Stock price of firm according to the research of author reflected with profit information of firm, however, information on the statement of cash flows, stock price has not also affected all times. In an inefficient market, stock price, dividend paid for the shareholder related to the expenditure and profit of firms such as pure income, basic interest on securities. Research showed although information on cash flows of firm is not good, it showed that firm is not able to pay in future, however, the investor has still continued to purchase the stock of firm and the creditor still continues let firm borrow money. For an inefficient market, profit target is the most important target. Information on the cash flow statement are announced in public, however, all of creditors and investors are not interested in the information on statement. This affirmation and supplementing the information on using the cash flow statement. Mill \& Yamamura (1998) showed that information user such as investors and creditor in an inefficient information market, often lacking the skills and understanding related to money of firm. They showed that stock analysts or auditors rarely use the targets related to cash flows in order to analyze and recognize the firm. The user of information on the financial statement will pay more attention to the profit information of firm than information on cash flow of firm. If information on business condition of firm is good, information on cash flow statement is often less paid attention by the user. The author often not emphasizes on the important role, usefulness of cash flow statement in making decisions on operating the information user which rarely uses the information on the cash flows statement to make decisions.

Through literature review, studies are done in the developed economic countries, using information on the financial statements is often different from the countries has an economy like Vietnam, especially, Vietnam stock market is considered an inefficient information market. The market of ineffective information will have a great impact on individual investors who are perceived as having a lack of skills in evaluating the firms. Therefore, we want to investigate the impact of the cash flow statement on the decisions of individual investors.

\section{Research methodology}

Investors are entitled to select the shareholders in the firms posted on the stock market. Survey note will find out about the decision of investor changed or not as lacking information form the cash flow statement. We has provided the survey note to 75 investors are the balanced sheet with the firm as there is information on statement of financial position, comprehensive statement with profit grown well posted on the stock exchange but there is no information on the cash flows statement and 75 investors are still the firms having further information on the cash flow statement of firm with the operating activities on the cash flow statement. Financial statements of firms are audited on Ho Chi Minh Stock Exchange. The firms are entitled to select the opposed criterion very clearly between the profit and cash flows from operating activities. For the profit criterion is the criterion paid attention by the investors, firms have positive profit in two continuous report years, profit has increased three times, however, cash flow from operating activities is negative in two years of survey.

The investors are entitled to select accidentally from the shareholders of firm on Ho Chi Minh and Hanoi Stock exchange. Investors are made survey independently with each other, one person is not asked twice. By means of survey, the investors will reply with the researching question, 56\% is male. Age accounted for much in the research survey is the age from 26-35 years old accounts for about $42 \%$, the age from 36-45 years accounts for $34 \%$, the age of $46-55$ accounts for $14 \%$, the remaining is the age under 26 . The survey also showed that $74 \%$ of the investors have a university degree or master, $16 \%$ of the investors with university and college degrees and others only account for about $10 \%$. The majority of investors accounted for $82 \%$ of investors with experience of 3 years or more in investing in stock

To compare with difference in the decision of investor, we will use the $\mathrm{T}$ - test verification to verify the difference of investor in having or not information from the operating activities of firm. We have 2 table of T- test to verify the assumption.

$H_{1}$ : There is no difference in making decision of the investor with regards to show clearly the statement of financial position, comprehensive income statement in comparison with investors who have a full of financial statements

To recognize the business decision of the investor has an influence on the information on financial statement, we are able to refer on the regulations of American accounting. According to SFAC No. 02 (1980) and SFAC No. 05 (1984), financial statement has an influence on the decision of information user when it has reached the conformity of reported information brought back. Conformity of information on the financial statement is based on the element is the prediction in future on the basis of information provided by the firm at present and it can be evaluated on feeding back the investment is good whether or not. With regards to Vietnam, Ministry of Finance (2003) has a regulation that financial statement must be satisfied with suitable request to the demand of making an economic decision of users. Information in financial statement must be conformable with the interest of user, help 
them have an evidence on finding out about, evaluating on events, situation happened in past, present and future in order to make a conformable economic decision. Therefore, we have put forth two questions on evaluating the influence of cash flows statement for his own decision of investment based on the forecast of firm's stock price in future and feeds back on investments good or not good for the investor. The first question is the forecast of investor on the market impact on stock price of firm. This is a question forcasting on stock price in future. We have made the question for the investors evaluate how about the stock price of firm, whether stock price of firm is possible to increase in the next year. This is the market's perception of the stock price of this firm. This is predictive in investment decisions.

Question 1. Do you think that stock price of firm will increase or decrease in the next year?

The second question is evaluating the basic value of firm. This is a question related to the opinion and way of looking at the operating efficiency of firm in future. How are investors evaluating business value?

This question is reflective of this investment.

Question 2. Do you think that the investment in this firm is a good investment or not?

These questions are evaluated based on a 5-point Likert scale from 1 to 5 . We would like to research on the decision of investor is changed or not as there is no any information on the statement of cash flows. This article will show partially an influence of information on the cash flow statement until when the investor has made his own decision. We have implemented to verify the equality on average value of both overalls from information of two independent samples (Independent Samples T-test) for two groups of independent investors who have information on cash flows from operating activities. The Likert scale is numbered from 1 to 5 where 1 is the lowest level in the assessment as close to level 5 as the higher the rating.

After answering questions regarding investors' decisions on the case of the firm, in case of or without information from the cash flow statement, we ask the investors questions regarding investors' familiarity and comfort regarding their decisions. Through the 5-point Likert scale, we will compare two assessments about the comfort and confidence of investors' houses with or without information from cash flow statement. If the investor does not feel that there is any difficulty or problem that causes a lack of confidence in the analysis of the business, for users of cash flow statement information is not really necessary, they do not feel what if the analysis lacks information on the cash flow statement.

Researching confidence in performing the evaluation task is a very popular study with studies like Paese and Sniezek (1991); Wickam (2007). These studies show that people's attitudes affect their decisions, affecting whether information is needed or not. If the user of information has found out that is quite comfortable for his own decision although lacking the information in financial statement is really unnecessary. Decision of the investor is based on the fanilarity with skills in analysis, self confident comfort in recognizing the information as provided. We have also made the question on finding out about self confidence, comfort of investor changed or not as there is not full of information and when there is full of information on the statement of cash flows. Questions on the attitude of investor are made including:

\begin{tabular}{|c|c|c|c|c|c|}
\hline Question & 1 & 2 & 3 & 4 & 5 \\
\hline 1. This analytic investment is more difficult than previous your investment. & $\square$ & $\square$ & $\square$ & $\square$ & $\square$ \\
\hline $\begin{array}{l}\text { 2. Financial situation analysis of this firm, you have to spend more time in } \\
\text { analyzing the previous firms }\end{array}$ & $\square$ & $\square$ & $\square$ & $\square$ & $\square$ \\
\hline 3. You are sure in analyzing the financial situation of this firm & $\square$ & $\square$ & $\square$ & $\square$ & $\square$ \\
\hline
\end{tabular}

\section{Results and Discussion}

In comparison with the firms who have the positive profit, without any information on cash flow statement with positive profit, but cash flows from operating activities are negative. We have two tables to verify the equality on average value of two overalls from information of independent samples on evaluating the firm stock increasing or decreasing in future and investment in this firm is good or not. Average value on evaluating the firm stock increased or decreased in the next year for the information on operating cash flow only includes 3.79. As for the evaluation of investment is good or bad, when the information is not enough, the average value is 3.76 , with full information is 3.71 .

The first case has its meaning in observing and verifying Levene on equality of two overall equations (Levene's test) alternatively is $0.02<0.05$, so we shall use the result of two of overall variances unequally (Equal variances not assumed). With regards to verify the result has its meaning that is not necessary to rely on the level of meaning in observation ( $\mathrm{sig}$ ) in verifying the t-test for Equality of Means.

For the first verification on changing the stock price has its meaning in observation $(\mathrm{sig})=0.273>0.05$ so the information from cash flows from operating activities has not influence on stock price of firm will increase or decrease. The investor will change the personal decision as there is further information on cash flows from operating activities. The result is shown in table 1. 
Table 1: Verifying the Independent- samples T-test on difference in evaluating on stock in case of positive profit with or without any information on the cash flow statement Group Statistics

\begin{tabular}{|c|c|c|c|c|c|}
\hline \multirow{3}{*}{$\begin{array}{l}\text { Evaluating the stock } \\
\text { price of firm } \\
\text { increasing or } \\
\text { decreasing }\end{array}$} & Firm & $\mathrm{N}$ & Mean & Std. Deviation & $\begin{array}{l}\text { Std. Error } \\
\text { Mean }\end{array}$ \\
\hline & $\begin{array}{l}\text { Positive profit, there is no information on } \\
\text { the cash flows of operating activities }\end{array}$ & 75 & 3.79 & .643 & .074 \\
\hline & $\begin{array}{l}\text { Positive profit, cash flows from the } \\
\text { negative operating activities. }\end{array}$ & 75 & 3.65 & .830 & .096 \\
\hline
\end{tabular}

Independent Samples Test

\begin{tabular}{|c|c|c|c|c|}
\hline & \multicolumn{2}{|c|}{$\begin{array}{l}\text { Point of evaluating the stock } \\
\text { increasing or decreasing }\end{array}$} \\
\hline & & & Equal variances assumed & $\begin{array}{l}\text { Equal variances not } \\
\text { assumed }\end{array}$ \\
\hline \multirow{4}{*}{$\begin{array}{l}\text { Levene's Test for Equality of } \\
\text { Variances }\end{array}$} & $\mathrm{F}$ & & 5,505 & \\
\hline & Sig. & & .020 & \\
\hline & $\mathrm{T}$ & & 1,100 & 1,100 \\
\hline & Df & & 148 & 139.289 \\
\hline \multirow{5}{*}{$\begin{array}{l}\text { t-test for Equality of Means } \\
\text { Value }\end{array}$} & Sig. (2-tailed) & & .273 & .273 \\
\hline & Mean Difference & & .133 & .133 \\
\hline & Std. Error Differ & & .121 & .121 \\
\hline & $95 \%$ Confidence & Lower & -.106 & -.106 \\
\hline & $\begin{array}{l}\text { Interval of the } \\
\text { Difference }\end{array}$ & Upper & .373 & .373 \\
\hline
\end{tabular}

T-test is conducted for looking difference in evaluating that investments whether good or not good in case of positive with or without any information on the cash flow statements, shown on Table 2, below:

Table 2: Verifying the Independent- samples T-test on difference in evaluating on investments are good or not in case of positive profit with or without any information on the cash flow statement Group Statistics

\begin{tabular}{|c|c|c|c|c|c|}
\hline \multirow{3}{*}{$\begin{array}{l}\text { Point of evaluating the } \\
\text { investment in firm is } \\
\text { good or bad }\end{array}$} & Firm & $\mathrm{N}$ & Mean & $\begin{array}{c}\text { Std. } \\
\text { Deviation }\end{array}$ & $\begin{array}{l}\text { Std. Error } \\
\text { Mean }\end{array}$ \\
\hline & $\begin{array}{l}\text { Positive profit, there is no information on } \\
\text { the cash flow statement }\end{array}$ & 75 & 3.76 & .675 & .078 \\
\hline & $\begin{array}{l}\text { Positive profit, cash flow statement has the } \\
\text { cash flows from the negative operating } \\
\text { activities }\end{array}$ & 75 & 3.71 & .564 & .065 \\
\hline
\end{tabular}

Independent Samples Test

\begin{tabular}{|c|c|c|c|c|}
\hline & & & \multicolumn{2}{|c|}{ Point of evaluating the investment } \\
\hline & & & Equal variances assumed & $\begin{array}{c}\text { Equal variances not } \\
\text { assumed }\end{array}$ \\
\hline \multirow{2}{*}{$\begin{array}{l}\text { Levene's Test for } \\
\text { Equality of } \\
\text { Variances }\end{array}$} & $\mathrm{F}$ & & 2,741 & \\
\hline & \multicolumn{2}{|l|}{ Sig. } & .100 & \\
\hline \multirow{7}{*}{$\begin{array}{l}\text { t-test for Equality } \\
\text { of Means }\end{array}$} & \multicolumn{2}{|l|}{$\mathrm{T}$} & .525 & .525 \\
\hline & \multicolumn{2}{|l|}{ Df } & 148 & 143,501 \\
\hline & \multicolumn{2}{|l|}{ Sig. (2-tailed) } & .600 & .600 \\
\hline & \multicolumn{2}{|l|}{ Mean Difference } & .053 & .053 \\
\hline & \multicolumn{2}{|c|}{ Std. Error Difference } & .102 & .102 \\
\hline & \multirow{2}{*}{$\begin{array}{l}95 \% \text { Confidence } \\
\text { Interval of the } \\
\text { Difference }\end{array}$} & Lower & -.147 & -.147 \\
\hline & & Upper & .254 & .254 \\
\hline
\end{tabular}


The second test on meaning level in observation ( $\mathrm{sig}$ ) in the test of levene alternatively is $0.1>0.05$, so that we will be able to use the result of two equal variances assumed (Equal variances assumed). For this test, result is meaning or not that is necessary to rely on meaning level in observation (sig) in verifying the t-test for Equality of Means. The second test evaluates this amount of investment is good or bad, we also have meaning level in observation $(\mathrm{sig})=0.600>0.05$, so there is also not base to say that information on cash flows from operating activities will have an influence on recognizing this investment.

Two values of meaning level in this observation (sig) are much greater than level of meaning. By means of two testing tables: Independent - samples T-test showed there is not enough base for rejecting the assumption that no difference in the decision of investor for the case including or excluding the information on cash flows from operating activities in general or information on the cash flow statement in general as the firm has positive profit and cash flows from operating activities is negative. So, in case there is further information on cash flows of operating activities despite negative on contrary to the profit targets, but that article has not influence on the decision of investor as the profit is positive, equal growth through two years.

In case of having positive profit, investors will not pay attention to the cash flows from the operating activities although cash flow from operating activities is negative. However, when profit is negative, this article will have a lot of influence on the analysis of investor and information users will pay attention to the target of cash flows from operating activities than making own decisions.

Table 3: Average score of attitude, guarantee on making decision of investor as positive profit, with or without information on cash flow statement

\begin{tabular}{lccc}
\hline \multicolumn{1}{c}{ Questions } & $\begin{array}{c}\text { Positive profit, } \\
\text { statement of cash } \\
\text { flows }\end{array}$ & $\begin{array}{c}\text { Positive profit, there is no } \\
\text { information on the } \\
\text { statement of cash flows }\end{array}$ & Sig \\
\hline $\begin{array}{l}\text { 1. This investment analysis was more difficult } \\
\text { than the previous investment }\end{array}$ & 3.36 & 3.12 & 0.033 \\
$\begin{array}{l}\text { 2. Analyzing the financial situation at this firm } \\
\text { must spend more time than analyzing at the firms } \\
\text { before }\end{array}$ & 2.84 & 3.32 & 0.000 \\
$\begin{array}{l}\text { 3. Confident in analyzing the financial situation } \\
\text { in this firm }\end{array}$ & 3.04 & 2.63 & 0.000 \\
\hline
\end{tabular}

For the confident in analyzing the investments, lacking information also reduce the self confidence in analysis of the investors. As implementing to verify the Independent- samples T-test on difference between positive profit and there is no information on cash flows from operating activities and positive profit, cash flows from negative operating activities showed the average value alternatively is 2.63 and 3.04. Meaning level in observation (sig) < 0.05 , showed the difference on reliability in his own decision of the investor. Therefore, lacking information from the cash flow statement as positive profit did not change the decision of investor, however, reduced remarkably the confident of investor for investment amounts in firm.

\section{Conclusion}

This article showed that investors are mainly interested in the comprehensive statement reflecting the profit of firm, but less interested in the cash flow statement or cash flow is often reminded the most in monetary circulation is cash flow from operating activities. As the business profit is positive, stable growth, the investor will make a decision that does not have influence on information from the statement of cash flows. This is a point necessary to pay attention to the investors in making decisions. Due to the interest in profit expenditure, making a high profit will support for firms to be easier to attract the investment amounts. Therefore, profit of firm is also frequently adjusted because the managers are not able to adjust again. Cash flows from the cash flow statement of firms often reflect on bad and weak condition in the report of business results. If the investor has an intention to invest for long time that is necessary to pay attention to the information of cash flow statement. Stock market of Vietnam is acknowledged as market inefficient information, information is still unclear. In newly developed market, inefficient information on referring the information from statement has the character explicitly, honestly, it is not affected by the accounting estimation like the cash flow statement is very necessary

Comparing with financial statements of listed firms on the stock exchange, this is quite clear. Cash flow from operating activities is often only the report of business situation going down of firm before the targets comprehensive statement report of firm. For the cash flow statement, the investors should be interested in using the cash flow statement in combination with the information from other financial statement and recognizing the cash flows reflecting the financial situation of unit.

However, the firms listed on stock market should be more interested in providing the information on the financial statements especially in the statement of cash flows. Stock market is the place where firms are listed to attract the capital and promulgating the information in an evident manner, sufficiently, voluntarily as the best way to attract the monetary source of investord. At present, the cash flow statement has not been more interested by 
the investors, but in tendency of countries in the world, this statement will be more paid attention. Providing the information on cash flows statement as well as the information supplemented on the explanatory of financial statement will create a permanent trust for investors.

\section{References}

Allen, M.F. (2000), 'An experimental investigation of the incremental value of operating cash flows in decision making', Washington State University.

Barth, M.E. \& Cram, D.P. and Nelson, K.K. (2001), 'Accruals and the Prediction of Future Cash Flows', The Accounting Review, 76(1), 27-58. https://doi.org/10.2308/accr.2001.76.1.27

Carlin, T.M., Finch, N. \& Tran, M.D. (2015), 'Audit quality differences among auditors: The case of Hong Kong', Journal of Economics and Development, 17(1), 75-92.

Clinch, G \& Baljit Sidhu, B \& Sin, S. (2002), 'The Usefulness of Direct and Indirect Cash Flow Disclosures', Review of Accounting Studies, 7(4), 383-404.

Financial Accounting Standards Board (1980), 'Statement of Financial Accounting Concept No. 2: Qualitative Characteristics of Accounting Information'.

Financial Accounting Standards Board (1984), 'Statement of Financial Accounting Concept No. 5: Recognition and Measurement in Financial Statements of Business Enterprises', FASB.

Jackman, T.A. (2011), 'Corporate Bankruptcy and Prediction: An Analysis of Multi-discriminant, Logit and Survival Models Using the Statement of Cash Flows', University of Nebraska.

Ministry of Finance (2003), Decision No. 234/2003/QĐ-BTC on the accounting standard No 21 "Presentation on financial statement", as promulgated on $30^{\text {th }}$ December 2003.

Mills, J.R. \& Yamamura, J.H. (1998), 'The power of cash flow ratios', Journal of accountancy, 186(4), 53-61.

Sloan, R.G (1996), 'Do stock prices fully reflect information in accruals and cash flows about future earnings?', The Accounting Review, 71(3), 289-315.

Paese, P.W. \& Sniezek, J.A. (1991), 'Influences on appropriateness of confidence in judgment: Practice, effort, information and decision making'. Organizational Behavior and Human Decision, 48(1), 100-130. https://doi.org/10.1016/0749-5978(91)90008-H

Wampler, B. \& Smolinski, H.C. \& Vines, T. (2009), 'Making Stronger Statements: Cash Flow and Income', Strategic Finance, 91(4), 43-49.

Wickam, P.A. (2007), 'Overconfidence in new start-up success probability judgment', International Journal of Entrepreneurial Behavior \& Research, 12(4), 210-227. https://doi.org/10.1108/13552550610679168 